\title{
The Owadów-Brzezinki geoeducation area at Slawno
}

\section{Obszar geoedukacji Owadów-Brzezinki w Sławnie}

\author{
Błażej Błażejowski ${ }^{1 *(D)}$, Andrzej Wierzbowski² \\ ${ }^{1}$ Institute of Paleobiology, Polish Academy of Sciences, ul. Twarda 51/55, 00-818 Warszawa, Poland \\ ${ }^{2}$ Faculty of Geology, University of Warsaw, ul. Żwirki i Wigury 93, 02-089 Warszawa, Poland \\ bblazej@twarda.pan.pl,andrzej.wierzbowski@uw.edu.pl
}
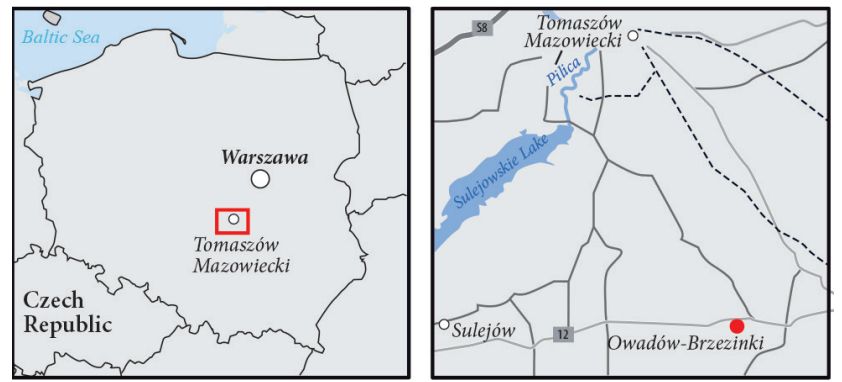

Article history:

Received: 13 September 2021

Accepted: 11 October 2021

Available online: 9 December 2021

(C) 2020 Authors. This is an open access publication, which can be used, distributed and reproduced in any medium according to the Creative Commons CC-BY 4.0 License requiring that the original work has been properly cited.

\begin{abstract}
The geoeducation area (called also "Owadów-Brzezinki Geopark") located in the north-western margin of the Holy Cross Mountains (Tomaszów Syncline) at Stawno community (Eódź Voivodeship), was established in June 2019, in close vicinity of the Owadów-Brzezinki quarry. This locality is one of the most important palaeontological sites described recently in Poland. The area consists of the exhibition pavilion, educational routs and panoramic viewing platform, which is located along the edge of the quarry. The palaeontological exhibition shows the unique Late Jurassic fossils of marine and terrestrial organisms, many of them new to science, that have been excavated in the quarry during the last eight years. Among the most important fossils are: ammonites, lobster-like decapod crustaceans, horseshoe crabs, actinopterygian fish, a cryptodiran turtle, ichthyosaurs, as well as a small terrestrial crocodyliform, pterosaurs and insects. In addition to the original fossils, the exhibition presents life-size reconstructions of animals, that inhabited the local seas and islands during the Late Jurassic. The palaeontological sites of Owadów-Brzezinki is referred to as a new "taphonomic window" of the Late Jurassic, providing insights about the evolution of life on Earth in the palaeogeographical and palaeoenvironmental context.
\end{abstract}

Keywords: geoeducation area-geopark, geotourism, fossils, Late Jurassic, Owadów-Brzezinki, Stawno

Treść: Geoedukacyjny ośrodek (zwany też „, Geoparkiem Owadów-Brzezinki”) znajdujący się na pólnocno-zachodnim obrzeżeniu Gór Świętokrzyskich (synklina tomaszowska) w gminie Stawno (województwo łódzkie) został utworzony w czerwcu 2019 roku w bliskim sąsiedztwie kamieniołomu Owadów-Brzezinki. Stanowisko to jest jednym z ważniejszych odkryć paleontologicznych ostatnich lat z terenu Polski. Ośrodek obejmuje pawilon wystawowy, ścieżki edukacyjne oraz platforme widokowa umiejscowiona w bezpośrednim sąsiedztwie kamieniołomu. W powstatym pawilonie paleontologicznym wyeksponowano unikatowe skamieniałości późnojurajskich zwierzą morskich i lądowych, w tym gatunki dotychczas nieznane, które zostały odkryte w kamieniołomie podczas ośmiu minionych lat. Do najważniejszych skamieniałości należą amonity, homaropodobne skorupiaki, skrzyplocze, ryby kostnoszkieletowe, żótwie skrytoszyjne, ichtiozaury, a także małe lądowe krokodylomorfy, pterozaury i owady. Oprócz oryginalnych skamieniałości w muzeum wyeksponowane sq naturalnych rozmiarów rekonstrukcje zwierząt, które zamieszkiwały lokalne morza i wyspy w późnej jurze. Stanowisko paleontologiczne Owadów-Brzezinki jest określane jako nowe „okno tafonomiczne” późnej jury, ukazujące zapis ewolucji życia na Ziemi w kontekście paleogeograficznym i paleośrodowiskowym.

Słowa kluczowe: geoedukacyjny ośrodek - geopark, geoturystyka, skamieniałości, późna jura, Owadów-Brzezinki, Sławno

\section{Introduction}

Palaeontological sites, where major scientific discoveries are made, often stimulate the imagination of those who take an interest in the history of life on Earth. They constitute the perfect foundation for the popularization of fields such as geology and palaeontology, and with time, they become particularly significant from the point of view of geotourism and tourist development of the regions in which they are located. 
In Central Europe, such geotourism destinations associated with important palaeontological discoveries are especially common in the rocks of the Jurassic System in Germany and Switzerland. Among the most interesting are: the Jura Museum Eichstätt at the Upper Jurassic limestone quarries in the region of Solnhofen-Eichstätt and the Hauff Museum, near the Lower Jurassic shales of the Holzmaden (Baden-Württemberg) region. In both of these regional palaeontological museums, the exhibition of original fossils is supplemented with natural-size reconstructions of animals.

In Poland, a site of similar type and of high scientific rank is the Owadów-Brzezinki quarry (Fig. 1), located about $20 \mathrm{~km}$ south of Tomaszów Mazowiecki, and at junction near the Warsaw-Katowice expressway. This site displays the Upper Jurassic carbonate rocks, which yield exceptionally interesting fossils of marine and terrestrial organisms (Kin et al., 2013; Błażejowski et al., 2016; Tyborowski et al., 2016). The ideal cooperation of the scientific community, the local government authorities of the Sławno commune and the owner of the Owadów-Brzezinki quarry (Nordkalk Company) resulted in the creation of a thematic geoeducation area (called also geopark; Fig. 2), the official opening of which took place in June 2019. It includes a palaeontological pavilion (Fig. 3) and geoeducational trails (Fig. 4), located in the immediate vicinity of the active quarry. The funds for construction of the exhibition pavilion and its surrounding were obtained from the European Regional Development Fund.

Due to the high scientific value of the Polish site and topics related to it, the palaeontological museum at pavilion was modeled on the previously mentioned famous European regional museums. Thus, both the scientific rank of the Polish palaeontological site and its geotourism potential were emphasized. The Owadów-Brzezinki area has all the qualities that can ensure success not only in activating the region through the development of tourism based on the use of geological heritage, but also through engaging the local community in the efforts of the local community and very intensive activities for geoeducation.

Although the name geopark has been introduced here in advance, when one considers all requirements and procedures necessary for the formal recognition of such a status (see e.g., Alexandrowicz, 2006), future activities would be undertaken to include that area into the formal geopark network, due to its educational and scientific significance. However so far, the formal status of the discussed territory from the standpoint of geoconservation is not definitely settled, and the name "Owadów-Brzezinki Geopark" is used in the non-standard meaning of the term "geopark".

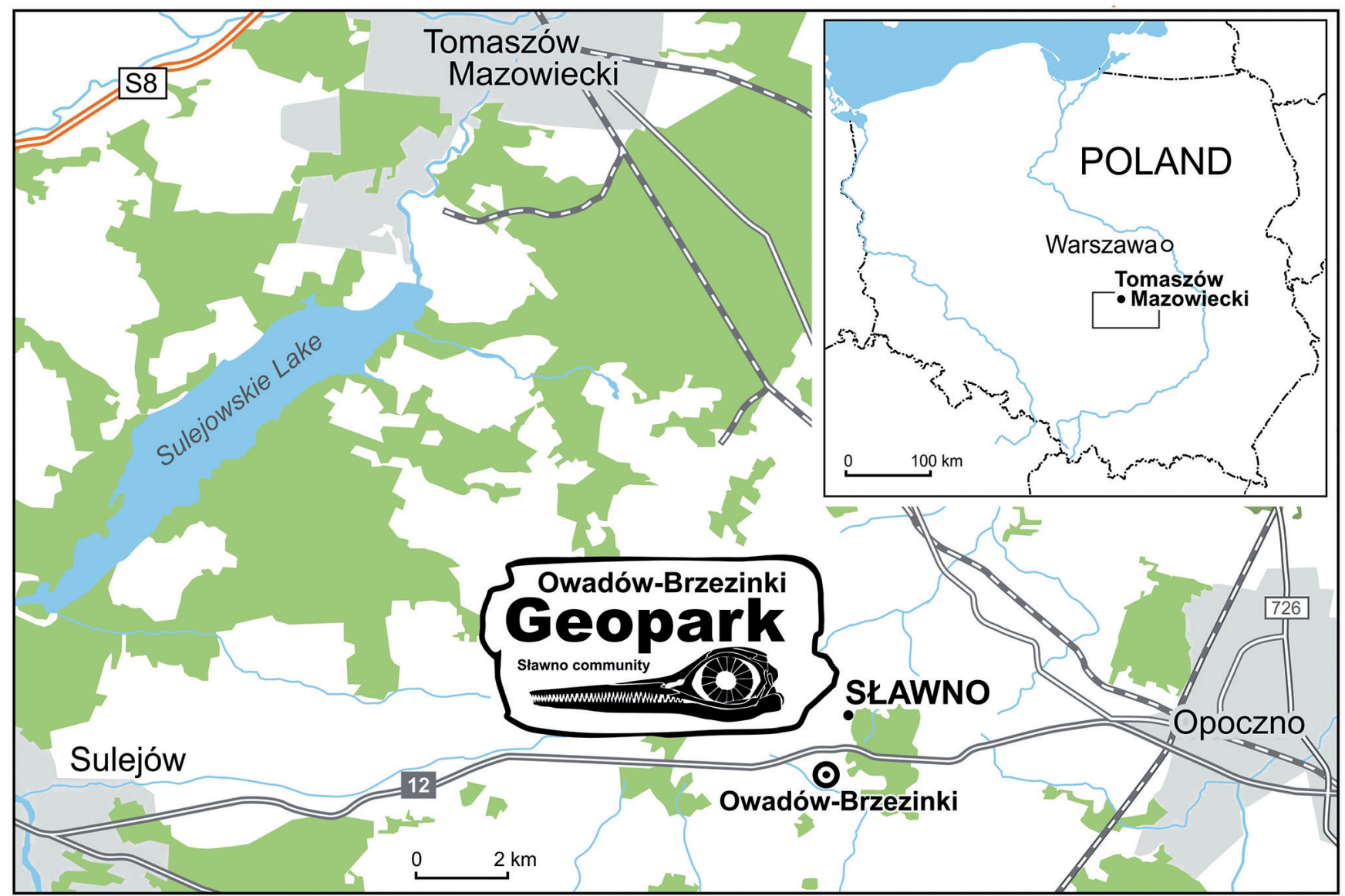

Fig. 1. Location map of the geoeductional area (“Owadów-Brzezinki Geopark”) 


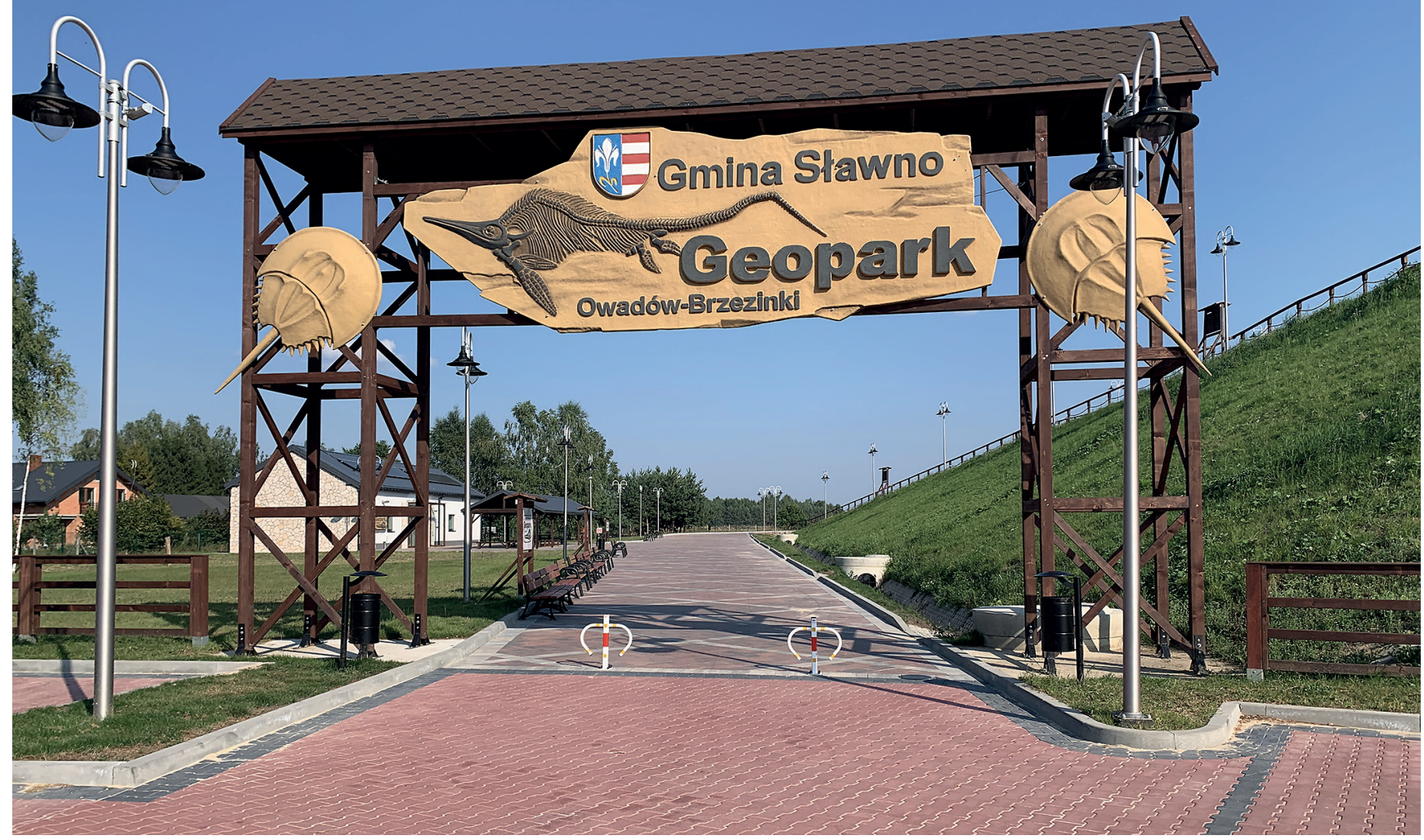

Fig. 2. The entrance gate to the Owadów-Brzezinki Geosite (geopark) in Sławno community. Photo B. Błażejowski

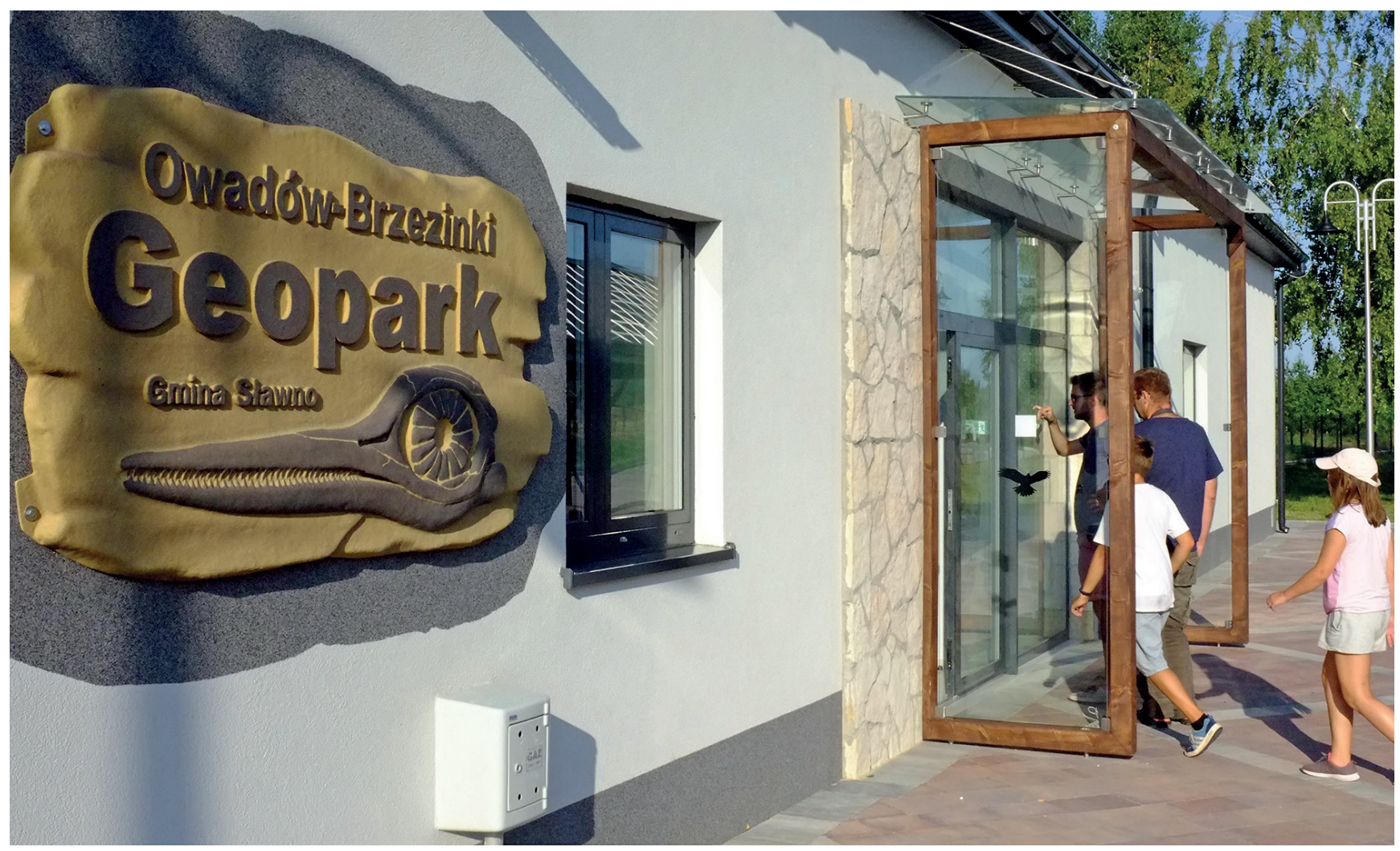

Fig. 3. Palaeontological pavilion in the Owadów-Brzezinki Geosite (geopark). Photo B. Błażejowski 


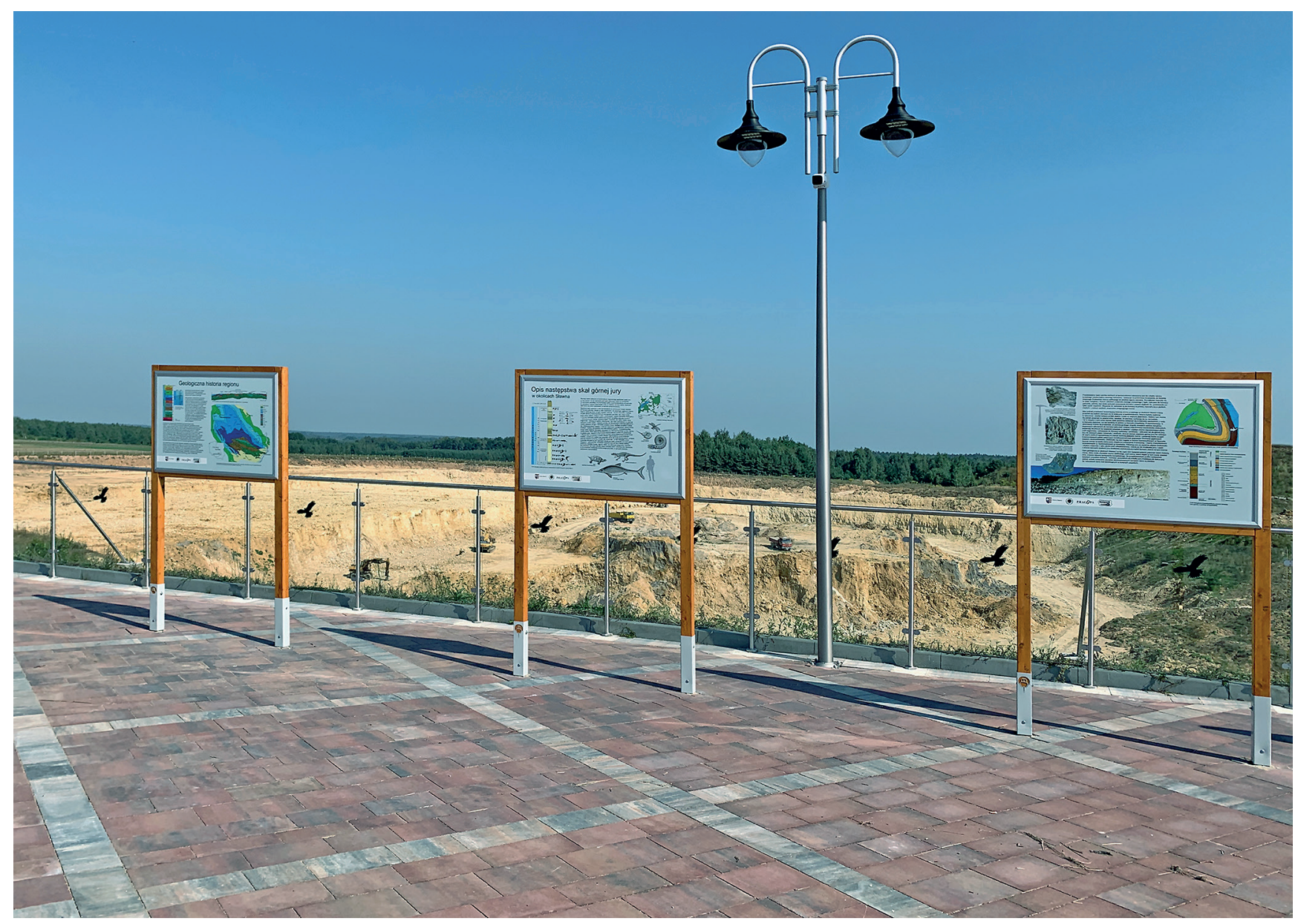

Fig. 4. Geoeducational trail on the panoramic viewing platform, located along the edge of the active quarry. Photo A. Błażejowska

\section{The geological setting of the Owadów-Brzezinki area and history of exploration}

The area is situated on the north-western margins of the Holy Cross Mts in the north-eastern limb of the Tomaszów Syncline. The Upper Jurassic carbonate succession attaining about $1000 \mathrm{~m}$ in thickness is represented in its uppermost part by the rocks mined in the Owadów-Brzezinki quarry (Sławno Commune) (Matyja \& Wierzbowski, 2014). The rocks exposed in the quarry belong to the uppermost stage of the Upper Jurassic - the Tithonian, and independently correlated with the local East European Substage - the Middle Volgian. Palaeontological excavations in the Owadów-Brzezinki quarry have been carried out since 2012 when Adrian Kin and Błażej Błażejowski (Geoscience Friends Association 'PHACOPS' and Institute of Paleobiology, Polish Academy of Sciences in Warsaw) announced the discovery of a new, unique palaeontological site of Fossil-Lagerstätte nature in the Sławno Commune.

Unusually well-preserved fossils of marine and terrestrial organisms of Late Jurassic (Tithonian) age have been documented for this site. It has been described in several dozen published scientific papers so far (see Kin \& Błażejowski, 2012; Błażejowski et al., 2016; Tyborowski et al., 2016). Although the quarry itself was known to geologists before (Kutek, 1994; Radwańska, 2003; Zielińska, 2003; Salamon et al., 2006), the discovery of strata with remarkably well-preserved fossils and the publication of the preliminary results of their research are very recent (Kin \& Błażejowski, 2012; Kin et al., 2013).

The excavation work carried out systematically since 2013, conducted at the Institute of Paleobiology PAS in Warsaw as part of a three-year research project (2013-2016) supported by the Polish National Science Centre (grant no. 2012/07/B/ ST10/04175), involved students, doctoral students and scientists from all around the world. The core of the scientific group supervising the conducted research aimed at exploring and documenting one of the most important palaeontological discoveries in Poland in recent years included: Błażej Błażejowski (leader of a grant, IPal PAS), Piotr Gieszcz (University of Warsaw), Bronisław A. Matyja (University of Warsaw), Daniel Tyborowski (Museum of the Earth in Warsaw, PAS), Andrzej Wierzbowski (University of Warsaw) and Hubert Wierzbowski (Polish Geological Institute - National Research Institute). 
The researches carried out to date have contributed to a better understanding of the evolutionary lines of many groups of animals, both vertebrates and invertebrates, as well as to documenting the palaeoenvironmental conditions and changes occurring in the Tithonian in Poland (Wierzbowski et al., 2016).

The rock layers, exposed in the quarry, bear the trace of environmental change in the Late Jurassic from a more open shelf sea to a shallow sea lagoon (Błażejowski et al., 2014, 2016). Initially, marly rocks were formed here, i.e., limestones with a high proportion of clay material, included in the Pałuki Formation. Later, perhaps as a result of a shift of climate to a drier one and the cessation of the flow of clay, only pure limestones were formed. These rocks, classified as belonging to the Kcynia Formation, were formed in the shallow, warm and clear waters of the gradually decreasing sea. The occasional anaerobic conditions and the accompanying set of biochemical processes were of particular importance for the preservation of the extraordinary palaeontological discoveries (Wierzbowski et al., 2016). As a result, the remains of organisms accumulated in the lagoon waters and were perfectly preserved in the fossil state.

\section{Fossils \\ as the main differentiator of the area}

There were many discoveries of marine life made in the Owadów-Brzezinka quarry, both of invertebrates - incl. ammonites (Matyja \& Wierzbowski, 2016), decapod crustaceans (Glypheoidea: Mecochiridae; Feldmann et al., 2015), horseshoe crabs (Chelicerata: Xiphosura; Błażejowski, 2015; Błażejowski et al., 2015a, 2019, 2020; Backnell et al., 2021) and vertebrate: the remains of various fish (Osteichthyes: Actinopterygii; Błażejowski et al., 2015b; Tyborowski, 2017), marine reptiles (Tyborowski et al., 2016): pancryptodiran turtle (Testudinata: Pancryptodira; Szczygielski et al., 2017) and ichthyosaurs (Ichthyosauria: Ophthalmosauridae; Tyborowski, 2016). The vast majority of the identified fossils represent hitherto unknown species, and their scientific description represents a significant contribution to understanding the life history of these groups of animals (Kin \& Błażejowski, 2014; Błażejowski et al., 2016).

During the Late Jurassic, the area of the European continent was covered by shallow seas, inhabited by diverse organisms in several distinct biogeographical provinces and sub-provinces. They were characterized by various faunas in the cool seas in the north of the continent, and significantly different ones in the warm seas in the south. The similarity and evolutionary links between the specimens found in the Owadów-Brzezinki quarry and the organisms known from other parts of Europe make it possible to conclude that there were existing sea connections enabling the free exchange of animals between different areas in the past. This factor is particularly relevant in the palaeogeographic interpretation, because contemporary marine sediments, indicating ancient sea connections, have been commonly not preserved, as they were removed by subsequent erosion. Such connections took place with the maritime areas of the Boreal region (terrain of today's Arctic) and Subboreal areas in the east and west - with the territory of today's European Russia and England, and periodically also with the southern areas, including the region of southern Germany and through the existing belt of the Štramberk-type coral reefs from the Tethys Ocean (Błażejowski et al., 2016; Matyja \& Wierzbowski, 2016; Pszczółkowski, 2016; Tyborowski, 2016; Tyborowski et al., 2016).

The site of Owadów-Brzezinki brings new data about the organic world of the Late Jurassic (placed near the Early/Late Tithonian boundary), showing not only the unknown record of the evolution of living organisms, but also the palaeogeography of Europe in the Late Jurassic. Palaeontological discoveries from the Owadów-Brzezinki quarry prove that the Sławno region was a palaeobiogeographic link between several regions in the Late Jurassic. It was here that the marine and terrestrial fauna from various parts of the continent met.

There was a small land or an archipelago of small islands in the sea near the place where the limestones mined in the Owadów-Brzezinki quarry were formed. This is where the land animals come from. One of the most interesting were the agile crocodylomorphs (Crocodylomorpha: Atoposauridae), whose well-preserved remains can be found in the local rocks. Above their heads soared flying reptiles (pterosaurs) and numerous insects (dragonflies, beetles, grasshoppers), the remains of which are also found in the rocks. The dragonfly species described here, which appeared new to the science, has been named Eumorbaeschna adriankini in honor of Adrian Kin, the discoverer of the first unique fossils at the Owadów-Brzezinka palaeontological site (Bechly \& Kin, 2013).

\section{Cooperation of three entities}

The discussed area is of importance not only for palaeontology as a science and popularization of this field in Poland, but also for the development of the region and its people. For several years now, workshops and lectures have been held in the Sławno Commune aimed at promoting knowledge of geology, and especially palaeontology, among the population of the region by initiating an atmosphere of understanding and respect for the natural environment. These activities are directed mainly to school children and youth, as well as to people interested in research and protection of the geological heritage of our country. It is also a potential place for national and international geological and palaeontological conferences. Of special importance for these activities and researches is the palaeontological pavilion, under the supervision of the Sławno Commune, where fossils of Jurassic animals discovered here (Fig. 5) and their reconstructions (Fig. 6) are displayed. The most spectacular specimens include natural-sized ammonites, fish and marine reptiles: ichthyosaurs and turtles, and crocodylomorphs, as well as a flying pterosaurs. The scientific team examining the fossils from this site supervised the creation of the exhibition at 
the museum (Fig. 7) and the plaques at the geo-educational path (Fig. 4), running on the observation deck along the edge of the quarry. The telescopes placed on the terrace allow one to observe the limestone exploitation works carried out by the owner of the quarry (Nordkalk Company), as well as research and exploration camps of scientists. In the central part of the observation deck there is a 12-meters long statue of the ichthyosaur, which is a symbol of the local palaeontological discoveries (Fig. 8).

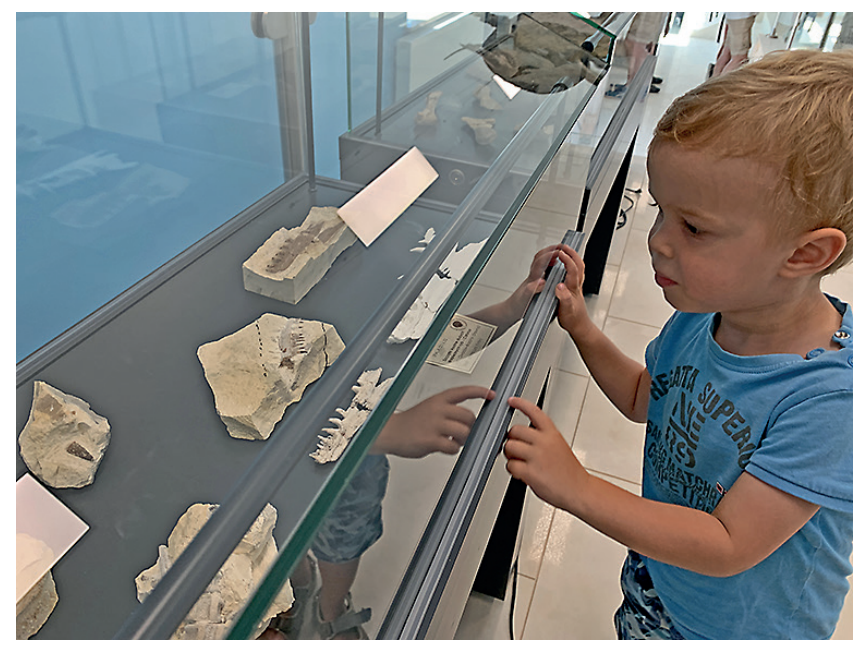

Fig. 5. Exhibition inside the palaeontological pavilion presenting fossils of Late Jurassic marine and terrestrial organisms found in the near quarry. Photo A. Błażejowska

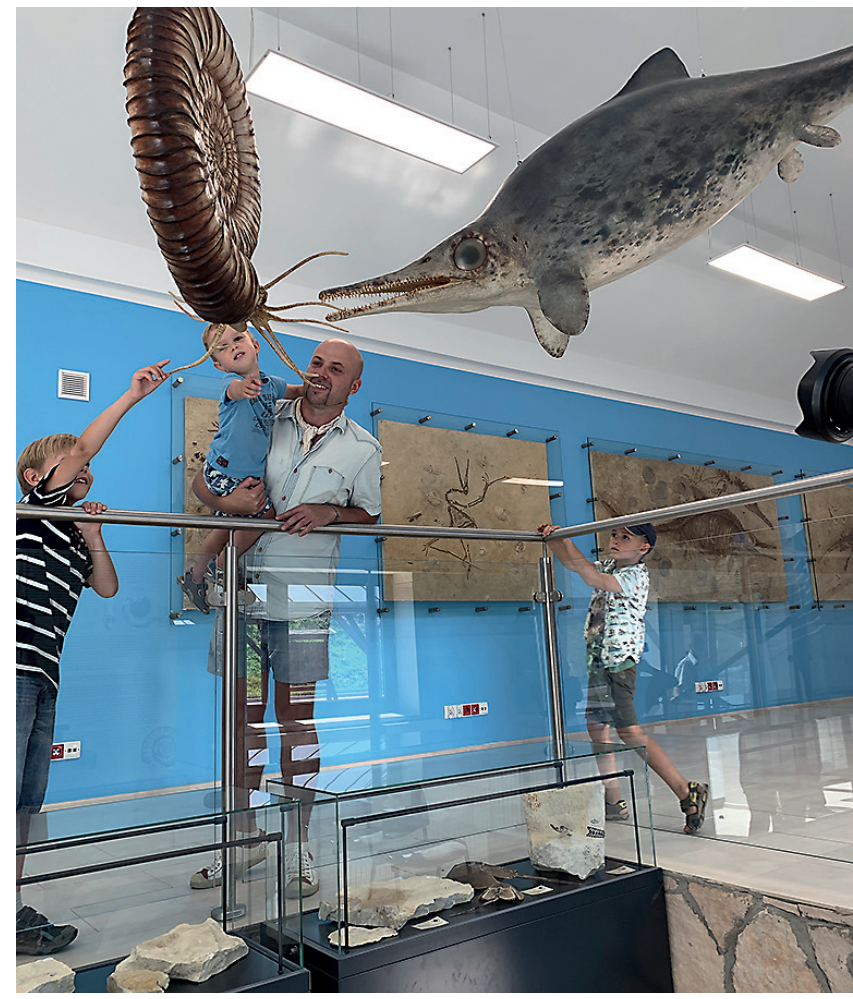

Fig. 6. The palaeontological pavilion presenting life-size reconstructions of animals which inhabited the local seas and islands during the Late Jurassic. Photo B. Błażejowski
Gathering, securing and researching this extraordinary collection of fossils is possible thanks to the excellent cooperation between the local government (Sławno Commune Office), Nordkalk Company (owner of the Owadów-Brzezinki Quarry) and the scientific community including various institutions (Institute of Paleobiology and Museum of the Earth, Polish Academy of Sciences; Polish Geological Institute National Research Institute; Geoscience Friends Association 'PHACOPS'; and Faculty of Geology, University of Warsaw).

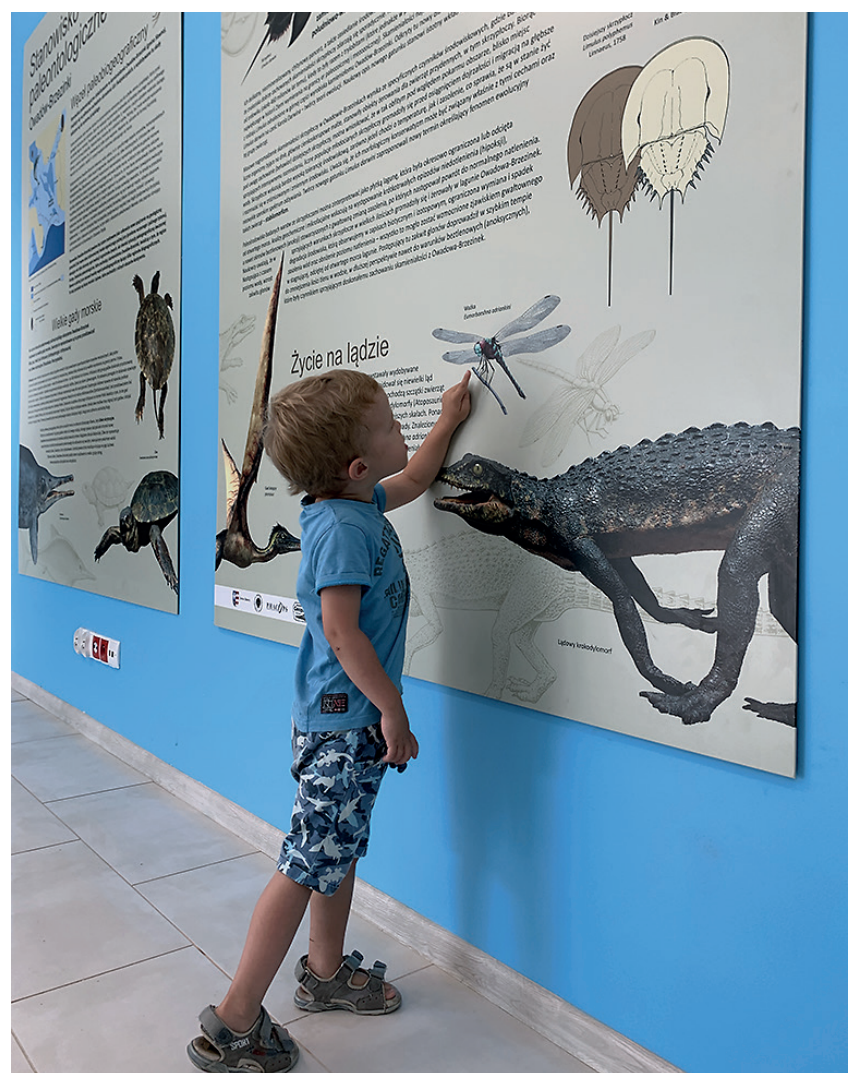

Fig. 7. On the walls, plates are located depicting the palaeogeographical and palaeoenvironmental history of the site. Photo A. Błażejowska

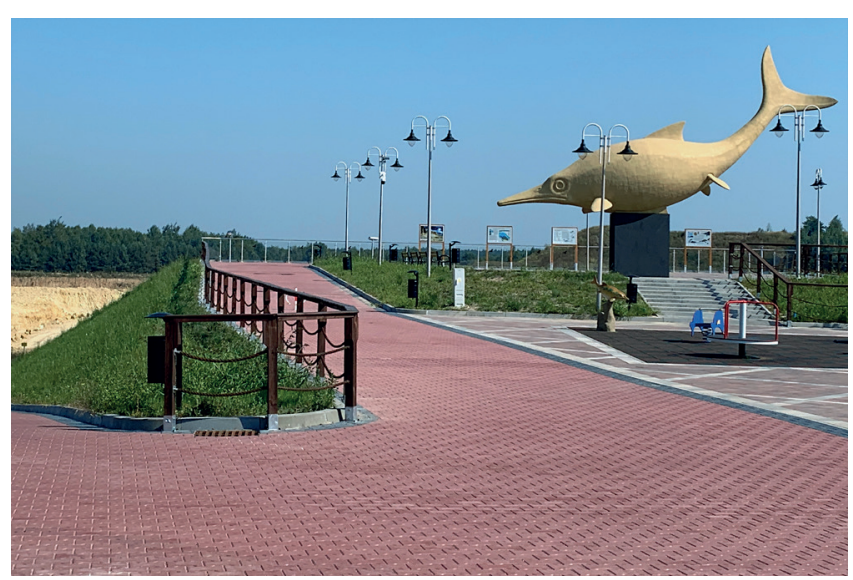

Fig. 8. The 12-meters long monument of the ichthyosaur, as the symbol of the geoeducational area (geopark) is exposed in the central part of the viewing platform. Photo A. Błażejowska 


\section{Acknowledgements}

We warmly acknowledge Bartłomiej Nowak (Managing Director), Sławomir Melka (Quarry and Production Manager) and Cezary Błaszczyk (Plant Manager) for the invaluable support that enabled the research in Owadów-Brzezinki Quarry (Nordkalk Company). We are grateful to Tadeusz
Wojciechowski (Mayor of Sławno Commune) for his invaluable support throughout the project over the years. We would like to sincerely thank all the students for assistance and support during fieldwork over many years. This work was supported by the Polish National Science Centre (grant no. 2020/39/B/ ST10/01489). Last but not least, we wish to acknowledge Ewa Głowniak (Univeristy of Warsaw) for her critical review and very helpful comments that improved the manuscript.

\section{References}

Alexandrowicz Z., 2006. Geoparki - nowe wyzwanie dla ochrony dziedzictwa geologicznego. Przegląd Geologiczny, 54(1): 36-41.

Bechly G. \& Kin A., 2013. First record of the fossil dragonfly family Eumorbaeschnidae from the Upper Jurassic of Poland. Acta Palaeontologica Polonica, 58(1): 121-124.

Bicknell R.D.C., Błażejowski B., Wings O., Hitij T. \& Botton M.L., 2021. Critical re-evaluation of Limulidae uncovers limited Limulus diversity. Papers in Palaeontology, 7(3): 1-32.

Błażejowski B., 2015. The oldest species of the genus Limulus from the Late Jurassic of Poland. In: Carmichael R.H., Botton M.L., Shin P.K.S. \& Cheung S.G. (eds.), Changing global perspectives on biology, conservation, and management of horseshoe crabs. Springer, New York: 3-14.

Błażejowski B., Matyja B.A. \& Wierzbowski A., 2014. A new exceptionally preserved Late Jurassic ecosystem (Owadów-Brzezinki, Central Poland) and its geological background. In: Feldman-Olszowska A. \& Wierzbowski A. (red. nauk.), Jurassica XI. Jurajskie utwory synkliny tomaszowskiej. Spotkanie Polsko-Stowackiej Grupy Roboczej Systemu Jurajskiego. Przewodnik wycieczek terenowych, abstrakty i artykuły. Spała 9-11.10.2014. Państwowy Instytut Geologiczny Państwowy Instytut Badawczy, Warszawa: 21-26.

Błażejowski B., Gieszcz P., Brett C.E. \& Binkowski M., 2015a. A moment from before $365 \mathrm{Ma}$ frozen in time and space. Scientific Reports (Nature Publishing Group), 5: 14191.

Błażejowski B., Lambers P., Gieszcz P., Tyborowski D. \& Binkowski M., 2015b. Late Jurassic jaw bones of Halecomorph fish (Actinopterygii: Halecomorphi) studied with X-ray microcomputed tomography. Palaeontologia Electronica, 18.3.53A: 1-10.

Błażejowski B., Gieszcz P. \& Tyborowski D., 2016. New finds of well-preserved Tithonian (Late Jurassic) fossils from the Owadów-Brzezinki Quarry, Central Poland: a review and perspectives. Volumina Jurassica, 14(1): 123-132.

Błażejowski B., Gieszcz P., Shinn A.P., Feldmann R.M. \& Durska E., 2019. Environment deterioration and related fungal infection of Upper Jurassic horseshoe crabs with remarks on their exceptional preservation. Palaeogeography, Palaeoclimatology, Palaeoecology, 516: 336-341.

Błażejowski B., Wierzbowski H. \& Feldmann R.M., 2020. Reply to the comment on "No evidence for fungal infection of Upper Jurassic horseshoe crabs: A comment on Błażejowski et al. (2019)" by Zatoń 2020. Palaeogeography, Palaeoclimatology, Palaeoecology, 554: 109733 .

Feldmann R.M., Schweitzer C.E. \& Błażejowski B., 2015. A new species of lobster (Glypheoidea: Mecochiridae) from the Late Jurassic (late Tithonian) Lagerstätte from central Poland. Neues Jahrbuch für Geologie und Paläontologie - Abhandlungen, 275(3): 107-114.

Kin A. \& Błażejowski B., 2012. Polskie Solnhofen. Przegląd Geologiczny, 60(7): 375-379.
Kin A. \& Błażejowski B., 2014. The Horseshoe Crab of the Genus Limulus: Living Fossil or Stabilomorph?. PLoS ONE, 9: e108036.

Kin A., Gruszczyński M., Martill D., Marshall J. \& Błażejowski B., 2013. Palaeoenvironment and taphonomy of a Late Jurassic (Late Tithonian) Lagerstätte from central Poland. Lethaia, 46(1): 71-81.

Kutek J., 1994. The Scythicus Zone (Middle Volgian) in Poland: its ammonites and biostratigraphic subdivision. Acta Geologica Polonica, 44(1-2): 1-33.

Matyja B.A. \& Wierzbowski A., 2014. Górna jura synkliny tomaszowskiej (północno-zachodnie obrzeżenie mezozoiczne Gór Świetokrzyskich). In: Feldman-Olszowska A., Wierzbowski A. (red. nauk.), Jurassica XI. Jurajskie utwory synkliny tomaszowskiej. Spotkanie Polsko-Stowackiej Grupy Roboczej Systemu Jurajskiego. Przewodnik wycieczek terenowych, abstrakty $i$ artykuty. Spała 9-11.10.2014. Państwowy Instytut Geologiczny - Państwowy Instytut Badawczy, Warszawa: 9-20.

Matyja B.A. \& Wierzbowski A., 2016. Ammonites and ammonite stratigraphy of the uppermost Jurassic (Tithonian) of the Owadow-Brzezinki quarry (central Poland). Volumina Jurassica, 14(1): 65-122.

Pszczółkowski A., 2016. A Tithonian Chitinoidella horizon in the Owadów-Brzezinki section (Central Poland). Volumina Jurassica, 14: $133-144$.

Radwańska U., 2003. Eko-tafonomia serpulitów tytonu Brzostówki i Sławna na tle badań wieloszczetów dzisiejszych. Tomy Jurajskie, 1(1): 99-104.

Salamon M., Zatoń M., Kin A. \& Gajerski A., 2006. Tithonian (Upper Jurassic) crinoids from Central Poland. Freiberger Forschungshefte, Paläontologie, Stratigraphie, Fazies C, 511: 29-38.

Szczygielski T., Tyborowski D. \& Błażejowski B., 2017. A new pancryptodiran turtle from the Late Jurassic of Poland and palaeobiology of early marine turtles. Geological Journal, 53(3): 1215-1226.

Tyborowski D., 2016. A new ophthalmosaurid ichthyosaur species from the Late Jurassic of Owadów-Brzezinki Quarry, Poland. Acta Palaeontologica Polonica, 61(4): 791-803.

Tyborowski D., 2017. Large predatory actinopterygian fishes from the Late Jurassic of Poland studied with X-ray microtomography. Neues Jahrbuch für Geologie und Paläontologie, 283(2): 161-172.

Tyborowski D., Błażejowski B. \& Krystek M., 2016. Szczątki gadów $\mathrm{z}$ górnojurajskich wapieni w kamieniołomie Owadów-Brzezinki (Polska środkowa). Przegląd Geologiczny, 64(8): 564-569.

Wierzbowski H., Dubicka Z., Rychliński T., Durska E., Olempska E. \& Błażejowski B., 2016. Depositional environment of Sławno limestones (uppermost Jurassic, central Poland): evidence from microfaciesanalysis, microfossils and geochemical proxies. Neues Jahrbuch für Geologie und Paläontologie, 282(1): 81-108.

Zielińska M., 2003. Ewolucja środowiska węglanowej sedymentacji późnego tytonu $w$ profilu kamieniołomu Stawno-Owadów w synklinie Tomaszowskiej. Wydział Geologii UW [M.Sc. thesis, unpublished]. 